\title{
The influence of a seabird colony on abundance and species composition of water bears (Tardigrada) in Hornsund (Spitsbergen, Arctic)
}

\author{
Krzysztof Zawierucha ${ }^{1}$ - Katarzyna Zmudczyńska-Skarbek ${ }^{2}$. \\ Eukasz Kaczmarek $^{1,3} \cdot$ Katarzyna Wojczulanis-Jakubas ${ }^{2}$
}

Received: 7 May 2015/Revised: 29 October 2015/Accepted: 30 October 2015/Published online: 12 November 2015

(C) The Author(s) 2015. This article is published with open access at Springerlink.com

\begin{abstract}
Seabirds in the Arctic are known to link marine and terrestrial ecosystems. They feed in the sea and breed on land, where they deposit enormous amounts of guano. Soil in the vicinity of seabird colonies is much more enriched with nutrients as compared to areas beyond their impact, which positively affects primary and secondary production. Water bears (Tardigrada) are microinvertebrates which constitute a permanent and ubiquitous faunal component of polar regions. Here, we tested the influence of seabird guano on Tardigrada communities; we established two transects in Hornsund (SW Spitsbergen): (1) SEABIRD where little auks (Alle alle) nested, and (2) CONTROL, an area without a little auk colony. In total, we collected 160 moss, lichen and mixed (moss/lichen) samples from those areas. In total, we found 1990 specimens belonging to 32 taxa ( 25 identified to species level). The average density of water bears was higher in the SEABIRD

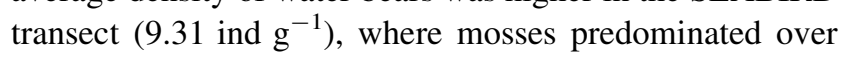
lichens, in comparison with the CONTROL transect $\left(5.83\right.$ ind $\left.\mathrm{g}^{-1}\right)$, where more lichens occurred. Thus, ornithogenic enrichment of soil and locally facilitated development of mosses over lichens might be important
\end{abstract}

Krzysztof Zawierucha

k.p.zawierucha@gmail.com

1 Department of Animal Taxonomy and Ecology, Faculty of Biology, Adam Mickiewicz University in Poznań,

Umultowska 89, 61-614 Poznań, Poland

2 Department of Vertebrate Ecology and Zoology, Faculty of Biology, University of Gdańsk, Wita Stwosza 59, 80-308 Gdańsk, Poland

3 Prometeo Researcher, Laboratorio de Ecología Natural y Aplicada de Invertebrados, Universidad Estatal Amazónica, Campus Principal Km 2.1/2 via a Napo (Paso Lateral), Puyo, Pastaza, Ecuador factors responsible for the increase in invertebrate abundance. According to canonical correspondence analysis, the little auk colony effect explained $13.2 \%$ of the tardigrade species composition, and this factor appeared to be more important than the vegetation type itself. Four taxa, i.e. Isohypsibius cf. reticulatus, Microhypsibius bertolanii, Minibiotus cf. formosus and Ramazzottius cf. rupeus, have been recorded in the Svalbard archipelago for the first time.

Keywords Little auk - Moss fauna $\cdot$ Lichen fauna $\cdot$ New records · Ornithogenic nutrients · Svalbard · Tundra

\section{Introduction}

Arctic terrestrial ecosystems are considered to be relatively species-poor, and this is mostly because of the harshness of the environmental conditions (e.g. low temperatures and nutrient concentrations, extreme seasonality). Limnoterrestrial Arctic invertebrate fauna are currently estimated at ca. 1000 named species (e.g. Coulson et al. 2014), while the counterpart number of other archipelagos is estimated to be twice that number and more; for instance, in nonArctic archipelagos, on the Galapagos (located in tropical zone) and the Azores (located in temperate zone), the number of invertebrate species exceeds 2000 (Herrera and Roque-Álbelo 2014; Base de Dados da Biodiversidade Dos Açores 2015). However, the low number of invertebrates identified may also be related to the fact that the Arctic has been poorly investigated (Coulson et al. 2014). Therefore, faunistic studies on invertebrate diversity are of great interest (Hodkinson 2013).

A growing amount of evidence suggests that some invertebrate species may be connected with very distinct microhabitats in the Arctic and, with conditions permitting, 
they may be locally abundant (e.g. Byzova et al. 1995; Sømme and Birkemoe 1999; Zmudczyńska et al. 2012; Zawierucha et al. 2015b). Such habitats are, for example, formed in the vicinity of seabird colonies. The supply of ornithogenic nutrients around these colonies, originating mainly from guano, significantly enhances soil conductivity, nitrogen, potassium and phosphate ion concentrations and decreases soil $\mathrm{pH}$ values, all of which dramatically change the environmental conditions (Mulder et al. 2011; Zmudczyńska et al. 2012; Zwolicki et al. 2013; Klimaszyk et al. 2015a, b). In polar regions, such fertilisation results in the development of exceptionally lush, compact and diverse plant and microbiota communities (Eurola and Hakala 1977; Odasz 1994; Ellis 2005; Zmudczyńska et al. 2008, 2009; Zmudczyńska-Skarbek et al. 2013), which in turn attracts populations of herbivores, predators, scavengers and decomposers (Croll et al. 2005; Jakubas et al. 2008; Zmudczyńska et al. 2012).

In this study, we examined assemblages of water bears (Tardigrada) with respect to the presence of a breeding colony of a pelagic seabird, i.e. the little auk Alle alle Linnaeus, 1758. Terrestrial tardigrades are a cosmopolitan phylum of microscopic metazoans ranging from ca. 100 to $2200 \mu \mathrm{m}$ in size. They inhabit various microhabitats within mosses, lichens, liverworts and soil. Many species are known to live in extreme conditions, e.g. on the highest mountain peaks and on the surface of glaciers (e.g. Ramazzotti and Maucci 1983; Nelson 2002; Guil 2008; Zawierucha et al. 2015a). Up to now, about 1200 tardigrade species have been described from different habitats throughout the world (Guidetti and Bertolani 2005; Degma and Guidetti 2007; Vicente and Bertolani 2013; Degma et al. 2009-2015). Terrestrial water bears are also a constant element of polar ecosystems, where they inhabit tundra and polar deserts (e.g. McInnes 1994; Convey and McInnes 2005; Zawierucha 2013; Zawierucha et al. 2013; Coulson et al. 2014). The number of tardigrade species from Svalbard consists of ca. 90 described species (Zawierucha et al. 2013).

Despite the water bears' ubiquitous distribution in polar regions (e.g. Ramazzotti and Maucci 1983; Dastych 1985; McInnes 1994) and the important role they play in food webs (Sohlenius and Boström 2008), ecological studies on this group have rarely been conducted in these ecosystems. Almost all previous research in Svalbard has focused mainly on descriptions of new species and/or the addition of new records (e.g. Węglarska 1965; Kaczmarek et al. 2012). The only two ecological studies that were conducted on the abundance and distribution of tardigrades were by Dastych (1985) and Zawierucha et al. (2015b), who showed the negative influence of altitude on tardigrade diversity. The impact of seabird guano on Tardigrada communities has been reported sporadically. In the
Antarctic, penguin guano negatively affected invertebrate assemblages, including tardigrades (Porazińska et al. 2002; Smykla et al. 2012). In the Arctic, no such an investigation has been performed; however, a recent study has shown that seabird guano positively influenced the water bears' body size (Zawierucha et al. 2015c).

Little auks are small planktivorous seabirds breeding exclusively in the High Arctic zone and are considered a keystone species of both marine and terrestrial ecosystems (Stempniewicz et al. 2007). With an estimated number of 37 million breeding pairs, these are the most abundant seabirds in the Atlantic Ocean (including Svalbard), and probably one of the most numerous seabirds in the world (Wojczulanis-Jakubas et al. 2011). Little auks are important consumers of sea resources, and due to the deposition of guano, feathers, egg shells and carcasses, while on land they are responsible for significant soil fertilisation, tundra productivity and diversity enhancement around their breeding colonies (Eurola and Hakala 1977; Jakubas et al. 2008; Zwolicki et al. 2013). This, in turn, is expected to be of an advantage to numerous invertebrates, including tardigrades.

The present research is focused on influence of seabird guano on tardigrade abundance and species composition. Specifically, we tested two hypotheses that: (1) tardigrades are more abundant in areas affected (in the vicinity of a little auk colony) as compared to areas non-affected by seabird guano (control area); and (2) species composition differs between these two areas.

Moreover, we report four taxa: (1) Microhypsibius bertolanii Kristensen, 1982, (2) Minibiotus cf. formosus (3) Ramazzottius cf. rupeus and (4) Isohypsibius cf. reticulatus, which have been recorded in the Svalbard archipelago for the first time.

\section{Materials and methods}

\section{Study area and field sampling}

The study was conducted in August 2011 on the northern coast of Hornsund (Wedel Jarlsberg Land, West Spitsbergen), within the limits of South Spitsbergen National Park (Fig. 1). The average annual temperature in the studied area is $-3.8{ }^{\circ} \mathrm{C}$ (Migała and Wawrzyniak 2013), and the soils are lithosols and frost-deformed regosols (Skiba 2013).

Two transects were established, each $1 \mathrm{~km}$ long: (1) SEABIRD - spanning from the seashore to the centre of the little auk colony situated on the slope of Ariekammen [ca. $77^{\circ} 01^{\prime} \mathrm{N} ; 15^{\circ} 31^{\prime} \mathrm{E}$; ca. 15,000 nesting pairs (Puczko and Stepniewicz 2013)], and (2) CONTROL-spanning from the seashore up the Fugleberget slope $\left(77^{\circ} 00^{\prime} \mathrm{N}\right.$, 
Fig. 1 Study area. Northern part of Hornsund, $\mathrm{S}-$ SEABIRD transect, $\mathrm{C}-$ CONTROL transect

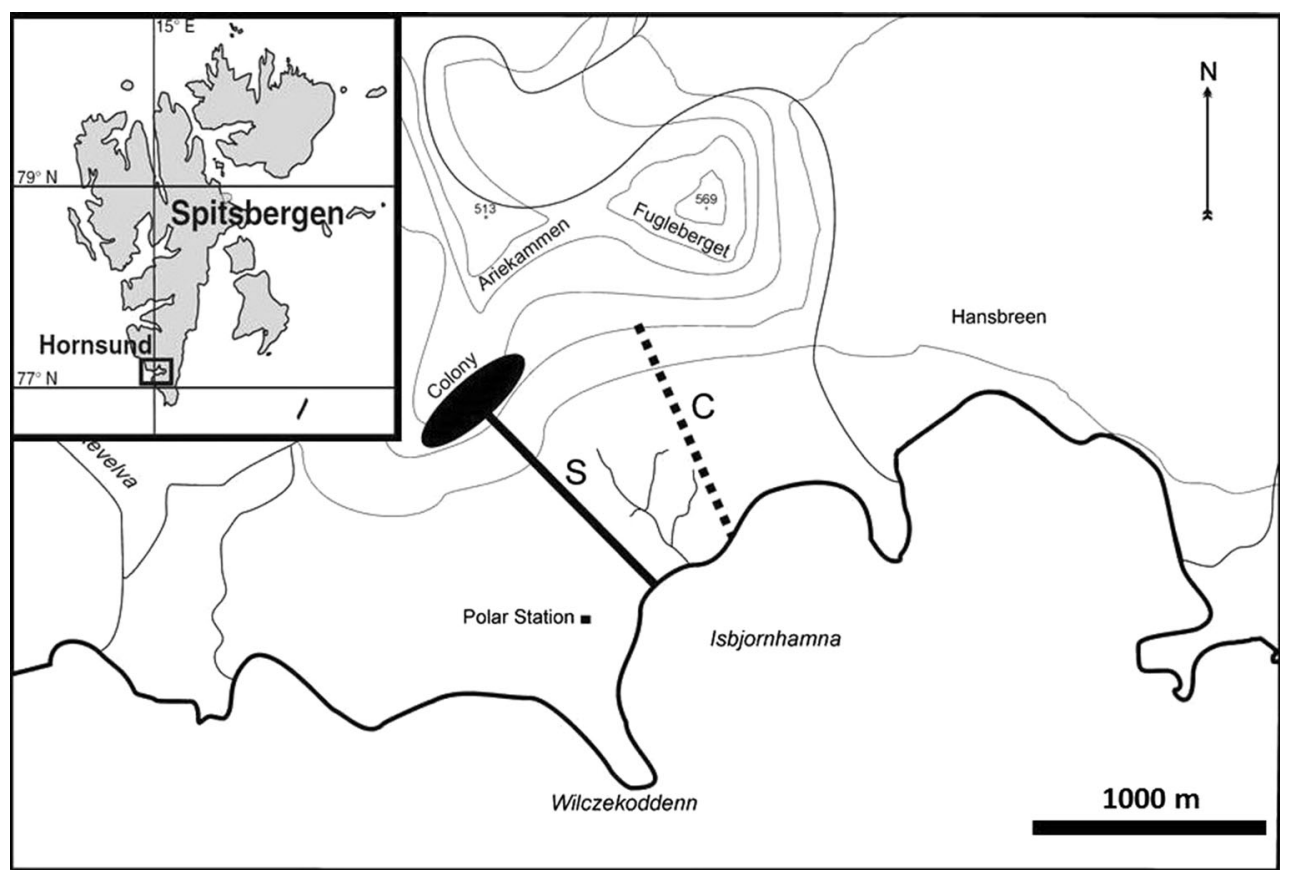

$15^{\circ} 33^{\prime} \mathrm{E}$ ) (Fig. 1). The whole SEABIRD transect was an area being under influence of the colony; it consisted of vegetation-covered rock debris and a near-horizontal tundra approaching the seashore. Plant communities occurring there are characteristic of well-fertilised bird-cliff vegetation (Rønning 1996), with vegetation cover of typically 90-95\%, except for the seashore. All samples of that transect were collected within the zone of vegetation modified by the birds. The CONTROL transect was situated outside the little auk colony and was not impacted directly by the birds' guano. It was situated on the site topographically similar to the SEABIRD transect, with patchy vegetation, mostly lichens. Both transects were oriented towards the $\mathrm{S}-\mathrm{E}$ and covered an altitudinal range from the sea level to ca. $72 \mathrm{~m}$ asl.

At each $100 \mathrm{~m}$, along both 1-km-long transects, a transverse sub-transect was established from which eight samples at five-metre intervals were collected ( $N=160$ in total) and classified as moss (M), lichen (L) or mixed (moss/lichen) (ML) samples. Each sample had size of ca. $1 / 3$ of the paper envelope (A4). All samples were later stored in the same envelopes, which allowed them to dry up slowly. Samples were weighed with a precision of $0.01 \mathrm{~g}$.

\section{Material extraction and species identification}

All samples were treated following standard methods for tardigrade examination (e.g. Dastych 1980; Ramazzotti and Maucci 1983). Each sample was soaked in water for ca. $5 \mathrm{~h}$. Water containing tardigrades and detritus particles was decanted and examined under a stereomicroscope. All extracted specimens, simplex, exuvia and eggs were mounted on microscope slides in Hoyer's medium and then examined using a Phase Contrast Microscope (PCM) (Olympus BX40) associated with an ART-CAM $300 \mathrm{MI}$ photo camera and QuickPhoto Camera 2.3 software. Species were identified using the key to World Tardigrada (Ramazzotti and Maucci 1983) and later original descriptions, re-descriptions and keys: Dastych (1985, 1988), Binda (1988), Bertolani and Rebecchi (1993), Tumanov (2007), Fontoura and Pilato (2007), Kaczmarek and Michalczyk (2009), Fontoura and Morais (2010), Kaczmarek et al. (2011a; 2012), Zawierucha (2013) and Zawierucha et al. (2014). All samples and microscope slides were deposited at the Department of Animal Taxonomy and Ecology at Adam Mickiewicz University in Poznań, Poland.

\section{Statistical analyses}

The number of tardigrades found in each sample was extrapolated for $1 \mathrm{~g}$ of dry mass of vegetation in order to calculate the total density, i.e. for all species together and for densities of particular species. Prior to this extrapolation, possible correlations were tested between a sample weight versus the number of individuals and number of species. No such correlation was found (Spearman rank correlations, $p>0.05$ for both individuals and species). All individuals which were not identified to species level (due to the lack of important taxonomic traits) were also included in comparisons of total density, but disregarded in 
species composition analyses. One outlying sample taken from the mossy-lichen habitat of the SEABIRD area was excluded from all the analyses because of the extremely high density of Isohypsibius coulsoni Kaczmarek et al., 2012 (955 ind $\mathrm{g}^{-1}$, the standardised value more than 12 ). Since five individuals of Ramazzottius cf. rupeus occurred only in this sample, the species was excluded from further analyses. We treated Paramacrobiotus richtersi (Murray, 1911) and Paramacrobiotus sp. as one taxon in the diversity and species composition analyses. Since a similar number of empty samples (with no individuals recorded) were found in the SEABIRD (25) and CONTROL (30) transects (Chi-square test, $\chi^{2}=0.69, p=0.41$ ), they were omitted from all analyses. The frequency of different vegetation type occurrences differed between the SEABIRD and CONTROL transects $\left(\chi^{2}=13.54, p=0.001\right)$. There were more $M$ samples within the SEABIRD area $\left(n_{S}=43\right.$ vs. $\left.n_{C}=26\right)$, while more L samples were within the CONTROL area $\left(n_{C}=12\right.$ vs. $\left.n_{S}=1\right)$. The number of ML samples in both areas was similar $\left(n_{S}=10\right.$ vs. $n_{C}=12$ ).

The Shannon diversity index was used to describe tardigrade species diversity $\left[H^{\prime}=\Sigma_{\mathrm{i}}\left(n_{i} N^{-1}\right) \log \left(n_{i} N^{-1}\right)\right]$, where $n_{i}$ is the number of individuals of species $i$ and $N$ is the total number of individuals, and evenness $\left[J^{\prime}=H^{\prime}(\log \right.$ $S)^{-1}$, where $S$ is the number of species] in the samples with the help of DIVer 10.o1 (AZB analysis and software 2010). To test for differences in total density and $H^{\prime}, J^{\prime}$ and the number of species between both transects and vegetation types, the nonparametric Mann-Whitney test and KruskalWallis with post hoc Dunn procedures were used (due to distinct deviations from normal distributions of the data; Shapiro-Wilk test, $p<0.05$ in all cases). These data were processed using STATISTICA 10.0 (StatSoft, Inc. 2011).

Numerical ordination methods were used to describe the total (qualitative and quantitative) variability of Tardigrada assemblages: (1) based only on species composition data to describe the general pattern of variability in the studied community (unimodal unconstrained analysis-detrended correspondence analysis, DCA; gradient length $=7.50$ $\mathrm{SD}$ ); and (2) in relation to two nominal environmental variables: transect-representing the presence (SEABIRD) or absence (CONTROL) of a seabird colony in the vicinity of the sampling sites, and vegetation-determining the type of vegetation from which the invertebrates were collected (unimodal constrained analysis-canonical correspondence analysis, CCA). Species occurring in only one sample were excluded from the analyses [besides the $R$. cf. rupeus as mentioned above, these were also: Echiniscus merokensis merokensis Richters, 1904, E. testudo (Doyère, 1840), Hebesuncus conjungens (Thulin, 1911), Microhypsibius bertolani Kristensen, 1982, Minibiotus cf. formosus, Pseudechiniscus victor (Ehrenberg, 1853), Richtersius coronifer (Richters, 1903), Tenuibiotus sp. and Tenuibiotus voronkovi (Tumanov, 2007)]. All species data were logtransformed in order to normalise their distributions. After the CCA, a Monte Carlo test was performed with 499 permutations to identify which of the factors significantly influenced the model. The variation partitioning test was used to calculate the factors' unique contribution in order to explain variability in the tardigrade species composition. The variation value was adjusted using the number of degrees of freedom as suggested by Peres-Neto et al. (2006) to provide a more accurate estimation of the variation explained with the use of the CCA. Each time the results of constrained ordination were compared with those of unconstrained ordination (\% variability explained by an environmental factor was divided by $\%$ variability explained by the first three axes of DCA). Thus, the efficiency of the environmental factor(s) was obtained in explaining the non-random variability existing in the data (\%). $T$ value biplots (Van Dobben circles) which approximated the $t$ values of the regression coefficients of a weighted multiple regression were employed to explore significant relationships between individual tardigrade species and the environmental factors. These data were processed using CANOCO 5.0 software (ter Braak and Šmilauer 2012).

\section{Results}

\section{Density of Tardigrada}

The total average density of tardigrades (all species together) was higher in the SEABIRD transect (median $=9.31$ ind $\mathrm{g}^{-1}$ ) as compared to the CONTROL (5.83 ind $\mathrm{g}^{-1}$ ), and the distribution of this parameter's values differed between the two areas (Mann-Whitney test, $z=2.01$, $p=0.044$; Fig. 2a). There were also significant differences in the density value distribution between different vegetation types (Kruskal-Wallis test, $H=12.73, p=0.002$; Fig. 2b). The highest tardigrade density was observed in the moss samples (vegetation type $\mathrm{M}$, median $=9.52$ ind $\mathrm{g}^{-1}$ ); a lower density was in the mixed (moss/lichen) samples (ML, 5.35 ind $\mathrm{g}^{-1}$ ); and the lowest was in the lichen samples ( $\mathrm{L}, 3.39$ ind $\mathrm{g}^{-1}$ ). However, only the difference between $\mathrm{M}$ and $\mathrm{L}$ was statistically significant (post hoc Dunn's test, $z=3.41, p=0.002$ ).

\section{Species composition}

In total, 1990 specimens belonging to 32 taxa (25 determined to species level) were found (Table 1). Due to the lack of eggs, some of the specimens were determined only to genus or species group level. Twenty-two taxa were 
Fig. 2 Comparison of total Tardigrada density [medians with interquartile ranges (boxes) and non-outliers (whiskers)] between the transects (a) and vegetation types (b).

Statistically significant differences marked (MannWhitney test)
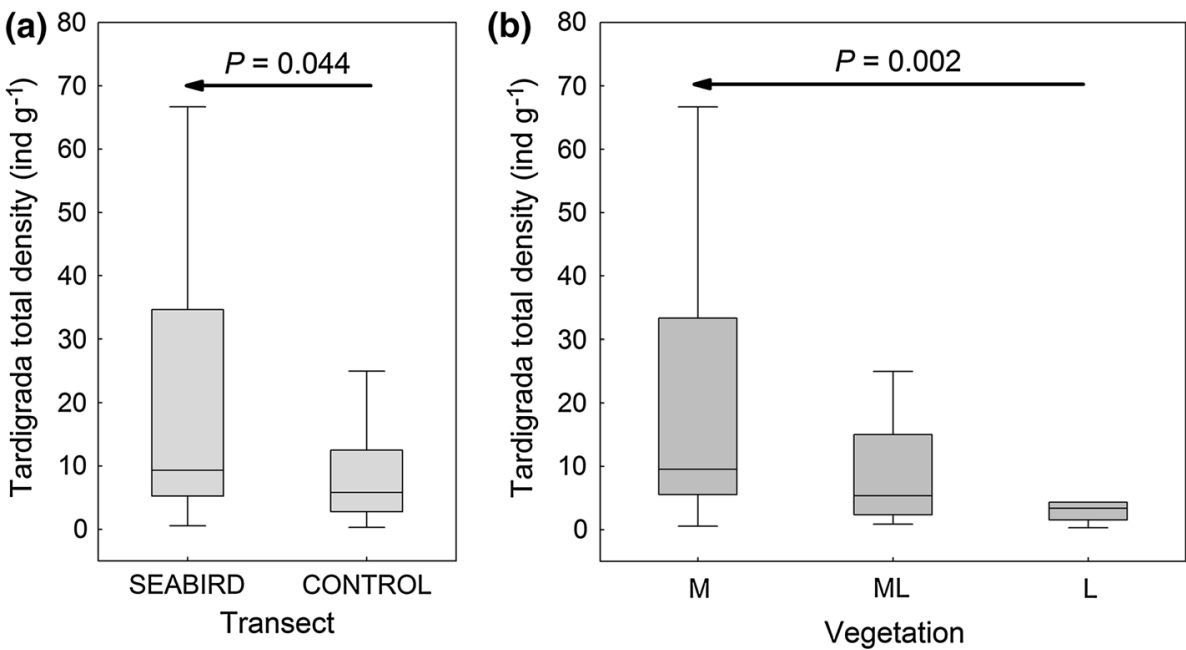

found in the SEABIRD transect and 24 in the CONTROL transect. Fifteen taxa were found in both transects; thus, seven were revealed only in the SEABIRD transect and ten only in the CONTROL. The most frequent tardigrade species in all of the samples was Pilatobius recamieri (Richters, 1911), which was present in 35 samples (in 29 and 6 samples from the SEABIRD and CONTROL transects, respectively).

There were no significant differences in the Shannon $H^{\prime}$ diversity index, the evenness $J^{\prime}$ index and the number of species between the SEABIRD and CONTROL transects, or between different vegetation types $(p>0.05)$. The CCA analysis revealed that both of the variables tested (transect and vegetation) together explained $16.2 \%$ of the nonrandom (i.e. described with DCA theoretical gradients: axis $1-10.5 \%$, axis $2-7.8 \%$, axis $3-5.1 \%$ ) variability of the Tardigrada assemblages (all canonical axes were significant; Monte Carlo permutation test, pseudo- $F=2.3$, $p=0.002)$. The transect factor was responsible for $13.2 \%$ ( $F=4.0, p=0.002)$ of the tardigrade variability, and $1.3 \%$ of this variation was partitioned with the vegetation factor (Fig. 3). The transect also had a significant unique contribution to explaining the tardigrades' composition (11.9\%,F=3.7, $p=0.002)$. However, the vegetation factor did not significantly differentiate the tardigrade communities either independently of the transect $(3.4 \%$, $F=1.5, p=0.078)$ or in addition to it $(4.3 \%, F=1.4$, $p=0.12$ ). Figure 4 presents 10 species best fitted to the ordination based on both variables, with their percentage occurrences in different transects. Species significantly positively associated with the SEABIRD transect were $I$. elegans, M. crenulatus Richters, 1904 and P. recamieri; while those related to the CONTROL were E. granulatus (Doyère, 1840), Hypsibius convergens (Urbanowicz, 1925), H. pallidus Thulin, 1911 and Testechiniscus spitsbergensis (Scourfield, 1897).
Four taxa, i.e. M. bertolanii, M. cf. formosus, $R$. cf. rupeus and $I$. cf. reticulatus, were recorded in the Svalbard archipelago for the first time.

\section{Discussion}

\section{Tardigrada abundance and species composition}

This is the first study that examined the influence of a planktivorous seabird colony on tardigrades in the Arctic, confirming the hypothesis presented in introduction. It was found that tardigrades were more abundant in the vicinity of the little auk colony as compared to areas not occupied by these birds. The density of Tardigrada was higher in the area influenced by the little auk colony as compared to the CONTROL transect. Unfortunately, it was not possible to compare the absolute values that were obtained here with results obtained in polar regions by other authors as these authors had calculated the densities of tardigrades in a different manner: (a) per area (e.g. Dastych 1985), (b) per weight of wet material (Everitt 1981) or (c) they completely omitted such calculations (e.g. Johansson et al. 2013). However, the average density $\left(9\right.$ ind $\mathrm{g}^{-1}$ ) recorded in the SEABIRD transect was comparable with our previous results from the Ariekammen and Rotjesfjellet slopes (Hornsund), which were also inhabited by little auks ( 9 ind $\left.\mathrm{g}^{-1}\right)$, although the elevation range sampled there (14-524 $\mathrm{m}$ asl, Zawierucha et al. 2015b) was much wider than in the present study (only 0-72 $\mathrm{m}$ asl). The average densities of water bears in the samples collected in Nordaustlandet and Edgøya and the northern part of Prins Karl Forland were only 6 ind $\mathrm{g}^{-1}$ (Zawierucha et al. 2013). Furthermore, the maximum number of specimens collected there was very low (only 25 ind $\mathrm{g}^{-1}$ ), while in the CONTROL and SEABIRD transects, it was much higher (253 
Table 1 List of taxa found in study with division on the vegetation type $(\mathrm{M}-$ moss, $\mathrm{L}-$ lichens, ML-moss/lichens) and transect (S-SEABIRD, CCONTROL)

\begin{tabular}{|c|c|c|c|c|c|}
\hline \multirow[t]{2}{*}{ Taxa } & \multicolumn{3}{|c|}{ Vegetation } & \multicolumn{2}{|c|}{ Transect } \\
\hline & M & $\mathrm{L}$ & $\mathrm{M} / \mathrm{L}$ & $\mathrm{S}$ & $\mathrm{C}$ \\
\hline Diphascon pingue pingue (Marcus, 1936) & + & + & + & + & + \\
\hline Echiniscus granulatus (Doyère, 1840) & + & + & & & + \\
\hline E. merokensis merokensis Richters, 1904 & + & & & + & \\
\hline E. quadrispinosus quadrispinosus Richters, 1902 & + & & + & + & + \\
\hline E. testudo (Doyère, 1840) & & & + & + & \\
\hline E. wendti Richters, 1903 & & + & + & + & + \\
\hline Hebesuncus conjungens (Thulin, 1911) & & & + & & + \\
\hline Hypsibius convergens (Urbanowicz, 1925) & + & & + & & + \\
\hline H. dujardini (Doyère, 1840) & + & + & + & + & + \\
\hline H. pallidus Thulin, 1911 & + & + & + & + & + \\
\hline Isohypsibius coulsoni Kaczmarek et al., 2012 & + & & + & + & + \\
\hline I. elegans Binda and Pilato, 1971 & + & & + & + & \\
\hline I. karenae Zawierucha 2013 & + & & & + & \\
\hline I. cf. reticulatus & + & + & & & + \\
\hline I. sattleri (Richters, 1902) & + & & & + & + \\
\hline I. cf. tuberculatus & + & + & + & + & + \\
\hline Macrobiotus crenulatus Richters, 1904 & + & & + & + & + \\
\hline M. islandicus islandicus Richters, 1904 & + & & + & + & + \\
\hline M. harmsworthi harmsworthi Murray, 1907 & + & + & + & + & + \\
\hline M. h. obscurus Dastych 1985 & + & & & + & \\
\hline M.hufelandi group & + & & + & + & + \\
\hline Microhypsibius bertolanii Kristensen 1982 & + & & & + & \\
\hline Minibiotus cf. formosus & & & + & & + \\
\hline Paramacrobiotus richtersi (Murray, 1911) & + & & & & + \\
\hline Paramacrobiotus sp. & + & & & + & \\
\hline Pilatobius recamieri (Richters, 1911) & + & & + & + & + \\
\hline Pseudechiniscus victor (Ehrenberg, 1853) & + & & & & + \\
\hline Ramazzottius cf. rupeus & & & + & + & \\
\hline Richtersius coronifer (Richters, 1903) & + & & & & + \\
\hline Testechiniscus spitsbergensis (Scourfield, 1897) & + & + & + & + & + \\
\hline Tenuibiotus sp. & + & & & & + \\
\hline Tenuibiotus voronkovi (Tumanov, 2007) & & + & & & + \\
\hline
\end{tabular}

and 1304 ind $\mathrm{g}^{-1}$, respectively). This is the first study that shows the positive effect of polar seabirds' guano on the abundance of tardigrades. In contrast, Porazinska et al. (2002) and Smykla et al. (2012) showed that guano deposited in penguin colonies in Antarctica caused a decrease in tardigrade abundance. The most probable explanations for this could be an extremely high concentration of guano and the accumulation of ornithogenic nutrients around the penguin nests due to their location on flat terrains, as well as considerable devastation of the vegetation by bird trampling (Tatur 1989; Smykla et al. 2007). Similarly, Zmudczyńska et al. (2012) showed that springtails abundance was generally much higher in the ornithogenic tundra in Hornsund as compared to areas far from the seabird nests. However, in the centre of the little auk colony as well as directly beneath the cliff inhabited by guillemots and kittiwakes, density values were lower than the maximum recorded there.

The effect of the little auk colony may be indirect, e.g. it could have been created through the deposition of guano and soil fertilisation that amended the conditions for plant growth in the vicinity of the colony which, in turn, favoured the formation of microhabitats that were attractive for the tardigrade communities. Specifically, ornithogenic enrichment of the soil facilitated the development of bryophytes over the lichens (otherwise commonly occurring in the Arctic tundra, Thomas et al. 2008), which appear to be important factors for tardigrade density. Nevertheless, it was found that tardigrades were more numerous in mosses than in lichens regardless of the 


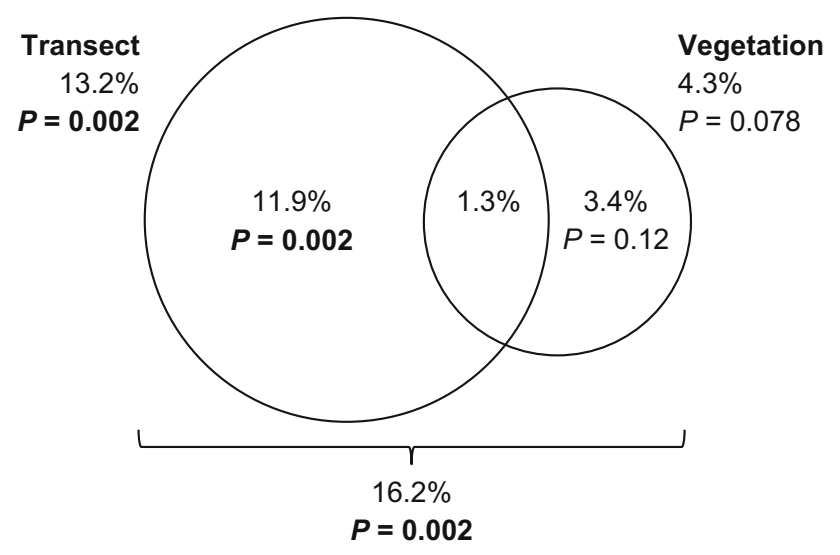

Fig. 3 Unique and shared fractions of the total variation in Tardigrada species composition explained by transect (SEABIRD and CONTROL) and vegetation (M-moss, $\mathrm{L}-$ lichens, ML-moss/ lichens)

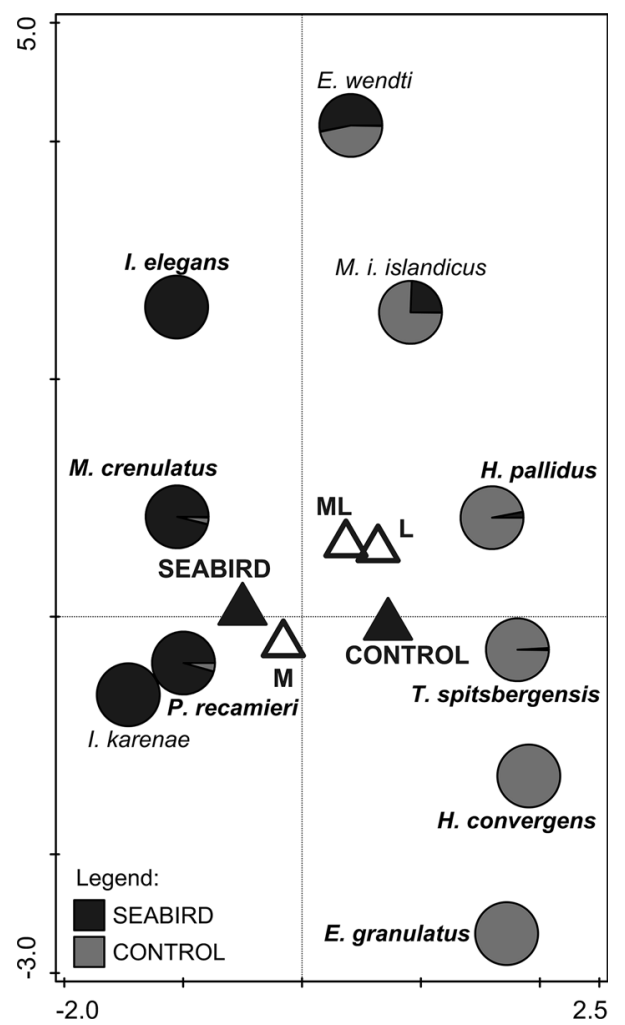

Fig. 4 CCA ordinations of 10 best fitted species to the transect (full triangles; SEABIRD and CONTROL) and vegetation (empty triangles; M-moss, L-lichens, ML-moss/lichens) factors, with pie slices based on the species percentage occurrence in different transects. Bold indicates species that significantly reacted to the transect (on the basis of $t$ value biplot). Diagram scaling focused on case distances

transect that was considered. Some authors have shown that tardigrades have species-specific preferences towards the different types of material that were examined, e.g. mosses, lichens and leaf litter (e.g. Dastych 1980, 1988;
Wright 1991; Guidetti et al. 1999; Jönsson 2003). Jönsson (2003) also demonstrated that the growth form of mosses might have some influence on tardigrade density, with "wefts" (mats) containing more individuals than other growth forms. Factors relating to the moss growth form, e.g. water-retention capacity, probably influence its suitability as a habitat for tardigrades (Jönsson 2003). However, the relationship between tardigrades and moss species (e.g. Kathman and Cross 1991), or even moss genera (Romano et al. 2001), has not been confirmed until today. Bartels and Nelson (2006) observed that tardigrade species' richness was always lower in lichens than in mosses in Great Smoky Mountains National Park (North Carolina, Tennessee, USA). Additionally, a study conducted in Costa Rican rainforests revealed that plant type had the weakest influence on tardigrade distribution (Kaczmarek et al. 2011b).

The effect of the seabird colony per se was responsible for $13.2 \%$ of the variability in the tardigrade assemblage. This suggests that additional factors, besides plant communities' alteration, accounted for species composition of the tardigrades around the seabird colony. One of these factors could be soil $\mathrm{pH}$, which was recognised to be lowered near little auk guano (Wait et al. 2005; Mulder et al. 2011; Zwolicki et al. 2013). Dastych (1985, 1988) divided tardigrade species into five categories with respect to their preferences for $\mathrm{pH}$ values: eucalciphil, polycalciphil, mesocalciphil, oligocalciphil and acalciphil. The SEABIRD transect should be classified as oligocalciphil or acalciphil (higher acidity), while the control area represented habitats of lower acidity (eucalciphil or polycalciphil). Most of the species found in the present study occurred in accordance with Dastych's $(1985,1988)$ assignment, and some of the species inhabit SEABIRD, and other CONTROL transect-oligocalciphil and eucalciphil, respectively (Fig. 4). However, three species were found in areas where they would not be expected given their assumed $\mathrm{pH}$ preferences and the soil $\mathrm{pH}$ within the transects. These were: E. testudo and I. elegans (apparently eucalciphil) found in the SEABIRD transect, and P. recamieri (acalciphil) found in both transects. While E. testudo can simply be a fortuitous faunal element in the SEABIRD transect (only one specimen recorded), the other two species were found in a higher number and could probably form stable populations.

A total of 32 taxa ( 25 determined to species level) were recorded that belonged to all ecological groups of tardigrades as distinguished by Guil and Sanchez-Moreno (2013): carnivores (e.g. species from genera Macrobiotus or Paramacrobiotus), herbivores (e.g. Echiniscus or Hypsibius) and microbivores (e.g. Diphascon). These records, along with previous studies carried out in the Ariekammen slopes and nearby areas (Węglarska 1965; 
Dastych 1985; Zawierucha et al. 2015b), comprise the list of 49 known species, up until today, from this region. This is very high number given the fact that biodiversity indices (Chao 2 and ICE) have estimated that the number of tardigrade species inhabiting the slopes of Rotjesfjellet and Ariekammen should range from 41 to 69 taxa (Zawierucha et al. 2015b). In fact, this is more than half of the total tardigrade species known from the entire Svalbard archipelago (i.e. almost ca. 90 species). It cannot be excluded that the high number of tardigrade species in the Ariekammen area is a result of the little auk colony. However, it may also indicate that the currently reported diversity of Svalbard tardigrades is remarkably underestimated. Many areas within the Svalbard archipelago have never been sampled or were sampled unsystematically. This clearly shows that there is a great need for studies on the tardigrade distribution in the Arctic in order to fully comprehend their ecology and to recognise the true biodiversity of Arctic ecosystems.

\section{New records}

Studies on Ariekammen slopes conducted in the past (Węglarska 1964; Dastych 1985) provided records of five species which were not found in the present study, i.e. $R$. oberhaeuseri (Doyère 1840), Tenuibiotus willardi (Pilato 1977), Milnesium tardigradum Doyère, 1840 sensu lato, Macrobiotus ariekammensis (Węglarska 1965) and Macrobiotus echinogenitus Richters, 1904 (Węglarska 1964; Dastych 1985). However, due to some taxonomic confusions (see, e.g. Michalczyk et al. 2012a, b), all of these species (excluding M. ariekammensis, which was described from this area) could have been misidentifications of the species found in the recent studies (e.g. Milnesium asiaticum Tumanov, 2006, M. eusrystomum Maucci, 1991). Zawierucha et al. (2015b) reported an additional sixteen species from this region: Adropion belgicae (Richters, 1911), A. prorsirostre (Thulin, 1928), A. scoticum scoticum (Murray, 1905), Bryodelphax parvulus Thulin, 1928, Calohypsibius ornatus (Richters, 1900), Diphascon tenue Thulin, 1928, Echiniscus blumi blumi Richters, 1903, E. capillatus Ramazzotti, 1956, Hypsibius microps Thulin, 1928, Isohypsibius prosostomus prosostomus Thulin, 1928, Macrobiotus hufelandi hufelandi Schultze, 1834, Milnesium asiaticum Tumanov, 2006, M. eusrystomum Maucci, 1991, Paramacrobiotus areolatus (Murray, 1907), Platicrista angustata (Murray, 1905) and Pseudechiniscus suillus (Ehrenberg, 1853).

Another four taxa were also found: Microhypsibius bertolanii (Kristensen 1982), Minibiotus cf. formosus, Ramazzottius cf. rupeus and Isohypsibius cf. reticulatus, which has never been recorded in the Svalbard archipelago. Thus, the total number of taxa from Ariekammen area is now 49.
The genus Microhypsibius Thulin, 1928 was recorded in Svalbard for the first time. Microhypsibius bertolanii was originally described from a homothermic spring and ponds in Greenland (Kristensen 1982). Here it was found in a moss sample collected within the SEABIRD transect, on the coastal plain $(11 \mathrm{~m}$ asl). Other species from the genus Microhypsibius are common in Arctic soils (Kristensen 1982), but the present findings extend $M$. bertolanii microhabitat preferences also to mosses.

So far, two species of the genus Minibiotus R.O. Schuster, 1980 have been reported from the Svalbard archipelago (Zawierucha et al. 2013). The second new record, Minibiotus cf. formosus, was found in the mixed, moss/lichen habitat within the CONTROL transect, and nominal species has been reported only from type locality in Estonia (Zawierucha et al. 2014). Although eggs were not found, the specimens corresponded well to the description presented by Zawierucha et al. (2014). This probably means that all older reports of species belonging to Minibiotus [especially M. intermedius (Plate, 1888)] reported from the Arctic need to be confirmed because of the increased number of new species being recorded for this genus. What is more, at present taxonomists are describing new species using taxonomic traits that were not considered important at the time when the Minibiotus representatives known from the Svalbard were reported (e.g. Claxton 1998; Fontoura et al. 2009). Thus, the number of species belonging to Minibiotus from the Svalbard archipelago can be much higher.

The genus Isohypsibius Thulin, 1928 is the most species-rich on the Svalbard archipelago (Zawierucha et al. 2013). Three species are endemic to Svalbard, and these are: I. ceciliae (Pilato and Binda, 1987), I. karenae (Zawierucha, 2013) and I. coulsoni (Pilato and Binda, 1987; Kaczmarek et al. 2012; Zawierucha 2013; Zawierucha et al. 2013). Isohypsibius reticulatus was previously known only from Italy (Sicily) and the former Yugoslavia (McInnes 1994), and so far, it was reported only from aquatic habitats (Pilato 1973). We found $I$. cf. reticulatus in mosses and lichen samples in the $\mathrm{CON}$ TROL transect. All records of $I$. reticulatus are based solely on morphological traits, but if molecular data in the future reveal great and discontinuous genetic variance between different populations of this taxon, the current opinion that the same species is known from the southern Europe and Spitsbergen may be refuted in favour of a species complex hypothesis.

Up to date, three species of the genus Ramazzottius Binda and Pilato, 1986 have been reported from the Svalbard archipelago (Zawierucha et al. 2013). Ramazzottius rupeus was originally described from lichens on Novaya Zemlya (Biserov 1999) and was known only from this locality. Although the eggs were not found, the 
specimens found in this study corresponded perfectly to the original description. Ramazzottius cf. rupeus was found in one mixed (moss/lichen) sample of the SEABIRD transect. All this together indicates that this species can be endemic to the Arctic region.

Every new record may underline the basic problem of knowing whether a species is newly establishing, alien/ invasive or a mere vagrant, or was previously recorded from a given area but, due to the lower quality of optical equipment or certain taxonomic problems, it was misidentified. Again, this highlights the great importance of conducting studies on the present sort by recognising biodiversity in the polar regions.

\section{Conclusions}

This is the first comprehensive investigation of the impact of a seabird colony on tardigrade communities. It showed the clear response of these invertebrates to the seabird colony which was expressed as increased abundance and differentiated species composition. The findings of the study highlight the ecological importance of ornithogenic nutrients for a terrestrial ecosystem in the Arctic, and the necessity of considering this factor in investigations of invertebrate diversity and distribution patterns. Moreover, four taxa that are new to the Svalbard archipelago were discovered. Such a number revealed in a limited area illustrates the poor state of knowledge on tardigrade assemblages in the Arctic. The Conservation of Arctic Flora and Fauna report underlines that available data on Arctic invertebrates are sparse and that there is still a lack of complex information on behavioural and physiological divergence among species or the food web (Hodkinson 2013). Thus, the present study constitutes a good background for a discussion about the factors influencing invertebrate diversity in the Arctic.

Acknowledgments We thank Dariusz Jakubas for help with sample collecting. The study was supported by Polish Ministry of Science and Higher Education via the "Diamond Grant" programme (Grant No. DIA 2011035241, to KZ) and partially by the Prometeo Project of the Secretariat for Higher Education, Science, Technology and Innovation of the Republic of Ecuador (to ŁK). Studies were conducted in the framework of activities of BARg (Biodiversity and Astrobiology Research group). KZ is a beneficiary of National Science Center scholarship for PhD No. 2015/16/T/NZ8/00017.

Open Access This article is distributed under the terms of the Creative Commons Attribution 4.0 International License (http://crea tivecommons.org/licenses/by/4.0/), which permits unrestricted use, distribution, and reproduction in any medium, provided you give appropriate credit to the original author(s) and the source, provide a link to the Creative Commons license, and indicate if changes were made.

\section{References}

AZB analysis \& software (2010) DIVer (diversity indices analysis software), version 10.o1, www.azb.com.pl

Bartels PJ, Nelson DR (2006) A large-scale, multihabitat inventory of the phylum tardigrada in the great smoky mountains National Park, USA: a preliminary report. Hydrobiol 558:111-118

Base De Dados Da Biodiversidade Dos Acores (2015) http://www. azoresbioportal.angra.uac.pt/publicacoes.php?lang=en. Accessed 04 May 2015

Bertolani R, Rebecchi L (1993) A revision of the Macrobiotus hufelandi group (Tardigrada, Macrobiotidae), with some observations on the taxonomic characters of eutardigrades. Zool Scripta 22:127-152

Binda MG (1988) Redescrizione di Macrobiotus echinogenitus Richters, 1904 e sul valore di buona specie di Macrobiotus crenulatus Richters, 1904 (Eutardigrada). Animalia 15:201-210

Biserov VI (1999) A review of the tardigrada from Novaya Zemlya; with description of three new species and an evaluation of the state of the environment in the region. Zool Anz 238:169-182

Byzova JB, Uvarov AV, Petrova AD (1995) Seasonal changes in communities of soil invertebrates in tundra ecosystem of Hornsund, Spitsbergen. Pol Polar Res 16:245-266

Claxton SK (1998) A revision of the genus Minibiotus (Tardigrada: Macrobiotidae) with descriptions of eleven new species from Australia. Rec Aust Mus 50:125-160

Convey P, McInnes SJ (2005) Exceptional, tardigrade dominated ecosystems in Ellsworth Land, Antarctica. Ecology 86:519-527

Coulson SJ, Convey P, Aakra K, Aarvik L, Ávila-Jiménez ML, Babenko A, Biersma EM, Boström S, Brittain JE, Carlsson AM, Christoffersen K, De Smet WH, Ekremj T, Fjellberg A, Füreder L, Gustafssonm D, Gwiazdowicz DJ, Hansen LO, Holmstrup M, Hullé M, Kaczmarek Ł, Kolicka M, Kuklin V, Lakka HK, Lebedeva N, Makarova O, Maraldo K, Melekhina E, Ødegaard F, Pilskog HE, Simon JC, Sohlenius B, Solhøy T, Søli G, Stur E, Tanasevitch A, Taskaeva A, Velle G, Zawierucha K, Zmudczyńska-Skarbek K (2014) The terrestrial and freshwater invertebrate biodiversity of the archipelagoes of the Barents Sea; Svalbard, Franz Josef Land and Novaya Zemlya. Soil Biol Biochem 68:440-470

Croll DA, Maron JL, Estes JA, Danner EM, Byrd GV (2005) Introduced predators transform subarctic islands from grassland to tundra. Science 307:1959-1961

Dastych H (1980) Niesporczaki (Tardigrada) Tatrzańskiego Parku Narodowego. Monografie Fauny Polski 9:1-232

Dastych H (1985) West Spitsbergen Tardigrada. Acta Zool Crac 28:169-214

Dastych H (1988) The tardigrada of Poland. Monografie Fauny Polski 16:1-255

Degma P, Guidetti R (2007) Notes on the current checklist of tardigrada. Zootaxa 1579:41-53

Degma P, Bertolani R, Guidetti R (2009-2015) Actual checklist of Tardigrada species. http://www.tardigrada.modena.unimo.it/mis cellanea/Actual $\% 20$ checklist $\% 20$ of\%20Tardigrada.pdf, pp. 40. Accessed 03 May 2015

Ellis JC (2005) Marine birds on land: a review of plant biomass, species richness, and community composition in seabird colonies. Plant Ecol 181:227-241

Eurola S, Hakala AVK (1977) The bird cliff vegetation of Svalbard. Aquilo Ser Bot 15:1-18

Everitt E (1981) An ecological study of an Antarctic freshwater pool with particular reference to Tardigrada and Rotifera. Hydrobiol $83: 225-237$

Fontoura P, Morais P (2010) Assessment of traditional and geometric morphometrics for discriminating cryptic species of the 
Pseudechiniscus suillus complex (Tardigrada, Echiniscidae). J Zool Syst Evol Res 49:26-33

Fontoura P, Pilato G (2007) Diphascon (Diphascon) faialense sp. n. a new species of Tardigrada (Eutardigrada, Hypsibiidae) from Azores and a key to the species of the $D$. pingue group. Zootaxa 1589:47-55

Fontoura P, Pilato G, Morais P, Lisi O (2009) Minibiotus xavieri, a new species of tardigrade from Parque Biologico de Gaia, Portugal (Eutardigrada: Macrobiotidae). Zootaxa 2267:55-64

Guidetti R, Bertolani R (2005) Tardigrade taxonomy: an updated checklist of the taxa and a list of characters for their identification. Zootaxa 845:1-46

Guidetti R, Nelson DR, Bertolani R (1999) Ecological and faunistic studies on tardigrades in leaf litter beech forests. Zool Anz 238:215-223

Guil N (2008) New records and within-species variability of Iberian tardigrades (Tardigrada), with comments on the species from the Echiniscus-blumi-canadensis series. Zootaxa 1757:1-30

Guil N, Sanchez-Moreno S (2013) Fine-scale patterns in micrometazoans: tardigrade diversity, community composition and trophic dynamics in leaf litter. Syst Biodivers 11:181-193

Herrera HW, Roque-Álbelo L (2014) CDF Checklist of Galapagos Terrestrial Invertebrates-FCD Lista de especies de Invertebrados terrestres de Galápagos. In: Bungartz F, Herrera H, Jaramillo P, Tirado N, Jiménez-Uzcátegui G, Ruiz D, Guézou A. Ziemmeck F (eds). Charles Darwin Foundation Galapagos Species Checklist-Lista de Especies de Galápagos de la Fundación Charles Darwin. Charles Darwin Foundation/Fundación Charles Darwin, Puerto Ayora, Galapagos: http://www. darwinfoundation.org/datazone/checklists/terrestrial-inverte brates/ Last updated 24 Sep 2014

Hodkinson ID (2013) Terrestrial and freshwater invertebrates. In: Meltofte $\mathrm{H}$ (ed) Arctic biodiversity assessment. Status and Trends in Arctic biodiversity. Conservation of Arctic Flora and Fauna, Akureyri, pp 194-223

Jakubas D, Zmudczyńska K, Wojczulanis-Jakubas K, Stempniewicz L (2008) Faeces deposition and numbers of vertebrate herbivores in the vicinity of planktivorous and piscivorous seabird colonies in Hornsund, Spitsbergen. Pol Polar Res 29:45-58

Johansson C, Miller WR, Linder ET, Adams BJ, Boreliz-Alvarado E (2013) Tardigrades of Alaska: distribution patterns, diversity and species richness. Polar Res 32:1-11

Jönsson KI (2003) Population density and species composition of moss-living tardigrades in a boreo-nemoral forest. Ecography 26:356-364

Kaczmarek Ł, Michalczyk Ł (2009) Redescription of Hypsibius microps Thulin, 1928 and $H$. pallidus Thulin, 1911 (Eutardigrada: Hypsibiidae) based on the type material from the Thulin collection. Zootaxa 2275:60-68

Kaczmarek Ł, Gołdyn B, Prokop ZM, Michalczyk Ł (2011a) New records of Tardigrada from Bulgaria with the description of Macrobiotus binieki sp. nov. (Eutardigrada: Macrobiotidae) and a key to the species of the harmsworthi group. Zootaxa 2781:29-39

Kaczmarek Ł, Gołdyn B, Wełnicz W, Michalczyk Ł (2011b) Ecological factors determining Tardigrada distribution in Costa Rica. J Zool Syst Evol Res 49:78-83

Kaczmarek Ł, Zawierucha K, Smykla J, Michalczyk Ł (2012) Tardigrada of the Revdalen (Spitsbergen) with the descriptions of two new species: Bryodelphax parvuspolaris (Heterotardigrada) and Isohypsibius coulsoni (Eutardigrada). Polar Biol 35:1013-1026

Kathman RD, Cross SF (1991) Ecological distribution of mossdwelling tardigrades on Vancouver Island, British Columbia, Canada. Can J Zool 69:122-129
Klimaszyk P, Piotrowicz R, Rzymski P (2015a) Changes in physicochemical conditions and macrophyte abundance in a shallow soft-water lake mediated by a Great Cormorant roosting colony. J Limnol 74:114-122

Klimaszyk P, Brzeg A, Rzymski P, Piotrowicz R (2015b) Black spots for aquatic and terrestrial ecosystems: impact of a perennial cormorant colony on the environment. Sci Total Environ 517:222-231

Kristensen RM (1982) New aberrant Eutardigrades from homothermic springs on Disko Island, West Greenland. In: Nelson DR (ed) Proceedings of the third international symposium on tardigrada. East Tennessee State University Press, Johnson City, pp 203-220

McInnes SJ (1994) Zoogeographical distribution of terrestrial/freshwater tardigrades from current literature. J Nat Hist 28:257-352

Michalczyk $Ł$, Wełnicz W, Frohme M, Kaczmarek $Ł$ (2012a) Redescriptions of three Milnesium Doyère, 1840 taxa (Tardigrada: Eutardigrada: Milnesiidae), including the nominal species for the genus. Zootaxa 3154:1-20

Michalczyk Ł, Wełnicz W, Frohme M, Kaczmarek Ł (2012b) Corrigenda of Zootaxa 3154: 1-20 Redescriptions of three Milnesium Doyère, 1840 taxa (Tardigrada: Eutardigrada: Milnesiidae), including the nominal species for the genus. Zootaxa 3154:1-20

Migała K, Wawrzyniak T (2013) Geographical environment in the vicinity of the Stanisław Siedlecki Polish Polar Station in Hornsund. Climate. In: Zwoliński et al (eds). Ancient and modern geoecosystems of Spitsbergen. Bogucki Wydawnictwo Naukowe, Poznań, pp 71-76

Mulder CPH, Jones H, Kameda K, Palmborg C, Schmidt S, Ellis JC, Orrock JL, Wait DA, Wardle DA, Yang L, Young H, Croll D, Vidal E (2011) Impacts of seabirds on plant and soil properties. In: Mulder CPH, Anderson WB, Towns DR, Bellingham PJ (eds) Seabird islands. Ecology, invasion and restoration. Oxford University Press, New York, pp 135-176

Nelson DR (2002) Current status of the Tardigrada: evolution and ecology. Integr Comp Biol 42:652-659

Odasz AM (1994) Nitrate reductase activity in vegetation below an Arctic bird cliff, Svalbard, Norway. J Veg Sci 5:913-920

Peres-Neto PR, Legendre P, Dray S, Borcard D (2006) Variation partitioning of species data matrices: estimation and comparison of fractions. Ecology 87:2614-2625

Pilato G (1973) Tardigradi delle acque dolci siciliane. Nota seconda. Boll sed Acc Gioenia Sc Nat Catania 12:295-296

Pilato G, Binda MG (1987) Isohypsibius ceciliae, nuova specie di Eutardigrado (Hypsibiidae) dello Spitsbergen. Animalia $14: 125-129$

Porazińska DL, Wall DH, Wirginia RA (2002) Invertebrates in ornithogenic soils on Ross Island, Antarctica. Polar Biol 25:569-574

Puczko M, Stępniewicz L (2013) Geographical environment in the vicinity of the Stanisław Siedlecki Polish Polar Station in Hornsund. Birds and mammals. In: Zwoliński $\mathrm{Z}$ et al (eds) Ancient and modern geoecosystems of Spitsbergen. Bogucki Wydawnictwo Naukowe, Poznań, pp 81-84

Ramazzotti G, Maucci W (1983) II Phylum Tardigrada (III. Edizione riveduta e aggiornata). Mem Ist Ital Idrobiol 41:1-1016

Romano FA III, Barreras-Borrero B, Nelson DR (2001) Ecological distribution and community analysis of Tardigrada from Choccolocco Creek, Alabama. Zool Anz 240:535-541

Rønning OS (1996) The flora of Svalbard. Norsk Polarinstitut, Oslo

Skiba S (2013) Geographical environment in the vicinity of the Stanisław Siedlecki Polish Polar Station in Hornsund. Soils. In: Zwoliński et al. (eds), Ancient and modern geoecosystems of Spitsbergen. Bogucki Wydawnictwo Naukowe, Poznań, pp 57-100 
Smykla J, Wołek J, Barcikowski A (2007) Zonation of vegetation related to penguin rookeries on king George Island, Maritime Antarctic. Arct Antarct Alp Res 3:143-151

Smykla J, Iakovenko N, Devetter M, Kaczmarek Ł (2012) Diversity and distribution of tardigrades in soils of Edmonson point (Northern Victoria Land, continental Antarctica). Czech Polar Rep 2:61-70

Sohlenius B, Boström S (2008) Species diversity and random distribution of microfauna in extremely isolated habitable patches on antarctic nunataks. Polar Biol 31:817-825

Sømme L, Birkemoe T (1999) Demography and population densities of Folsomia quadrioculata (Collembola, Isotomidae) on Spitsbergen. Nor J Entom 46:35-45

StatSoft, Inc. Team (2011) STATISTICA (data analysis software system), version 10. Oklahoma, StatSoft Inc, Tulsa

Stempniewicz L, Błachowiak-Samołyk K, Węsławski JM (2007) Impact of climate change on zooplankton communities seabird populations and arctic terrestrial ecosystem-a scenario. Deep Sea Res II 54:2934-2945

Tatur A (1989) Ornithogenic soils in the maritime Antarctic. Pol Polar Res 10:481-532

ter Braak CJF, Šmilauer P (2012) CANOCO reference manual and user's guide: software for ordination (version 5.0). Ithaca, New York: Microcomputer Power

Thomas DN, Fogg GE, Convey P, Fritsen CH, Gili JM, Gradinger R, Laybourn-Parry J, Reid K, Walton DWH (eds) (2008) The biology of polar regions. Oxford University Press, UK

Tumanov DV (2007) Three new species of Macrobiotus (Eutardigrada, Macrobiotidae, tenuis-group) from Tien Shan (Kirghizia) and Spitsbergen. J Lim 66:40-48

Vicente F, Bertolani R (2013) Considerations on the taxonomy of the Phylum Tardigrada. Zootaxa 3626:245-248

Wait DA, Aubrey DP, Anderson WB (2005) Seabird guano influences on desert islands: soil chemistry and herbaceous species richness and productivity. J Arid Environ 60:681-695

Węglarska B (1965) Die Tardigraden (Tardigrada) Spitzbergens. Act Zool Cracov 11:43-51

Wojczulanis-Jakubas K, Jakubas D, Welcker J, Harding AMA, Karnovsky NJ, Kidawa D, Steen H, Stempniewicz L, Camphuysen CJ (2011) Body size variation of a high-Arctic seabird: the dovekie (Alle alle). Polar Biol 34:847-854

Wright JC (1991) The significance of four xeric parameters in the ecology of terrestrial Tardigrada. J Zool Lond 224:59-77
Zawierucha K (2013) Tardigrada from Arctic tundra (Svalbard, Spitsbergen) with a description of Isohypsibius karenae (Eutardigrada: Isohypsibiidae). Pol Polar Res 34:383-396

Zawierucha K, Coulson J, Michalczyk Ł, Kaczmarek Ł (2013) Current knowledge on the Tardigrada of Svalbard with the first records of water bears from Nordaustlandet (High Arctic). Polar Res 32:20886. doi:10.3402/polar.v32i0.20886

Zawierucha K, Dziamięcki J, Jakubowska N, Michalczyk Ł, Kaczmarek $€$ (2014) New tardigrade records for the Baltic states with a description of Minibiotus formosus sp. nov. (Eutardigrada, Macrobiotidae). Zookeys 408:81-105

Zawierucha K, Kolicka M, Takeuchi N, Kaczmarek Ł (2015a) What animals can live in cryoconite holes? A faunal review. J Zool 295:159-169

Zawierucha K, Smykla J, Michalczyk Ł, Gołdyn B, Kaczmarek Ł (2015b) Distribution and diversity of Tardigrada along altitudinal gradients in the Hornsund, Spitsbergen (Arctic). Polar Res 34:24168. doi:10.3402/polar.v34.24168

Zawierucha K, Cytan J, Smykla J, Wojczulanis-Jakubas K, Kaczmarek Ł, Kosicki JZ, Michalczyk Ł (2015c) Seabird guano boosts body size of water bears (Tardigrada) inhabiting the Arctic tundra. Polar Biol 38:579-582

Zmudczyńska K, Zwolicki A, Barcikowski M, Iliszko L, Stempniewicz L (2008) Variability of individual biomass and leaf size of Saxifraga nivalis L. along a transect between seabirds colony and seashore in Hornsund, Spitsbergen. Ecol Quest 9:37-44

Zmudczyńska K, Zwolicki A, Barcikowski M, Barcikowski A, Stempniewicz L (2009) Spectral characteristics of the Arctic ornithogenic tundra vegetation in Hornsund area, SW Spitsbergen. Pol Polar Res 30:249-262

Zmudczyńska K, Olejniczak I, Zwolicki A, Iliszko L, Convey P, Stempniewicz L (2012) Influence of allochtonous nutrients delivered by colonial seabirds on soil collembolan communities on Spitsbergen. Polar Biol 35:1233-1245

Zmudczyńska-Skarbek K, Barcikowski M, Zwolicki A, Iliszko L, Stempniewicz L (2013) Variability of polar scurvygrass Cochlearia groenlandica individual traits along a seabird influenced gradient across Spitsbergen tundra. Polar Biol 36:1659-1669

Zwolicki A, Zmudczyńska-Skarbek KM, Iliszko L, Stempniewicz L (2013) Guano deposition and nutrient enrichment in the vicinity of planktivorous and piscivorous seabird colonies in Spitsbergen. Polar Biol 36:363-372 